\title{
By-products of Piper aduncum in the control of fusariosis in black pepper plant
}

\author{
Ruth Linda Benchimol' ${ }^{1}$, John Clifford Sutton², Cleber Novais Bastos ${ }^{3}$, \\ Carina Melo da Silva ${ }^{4}$, Moacyr Bernardino Dias-Filho ${ }^{1}$
}

\begin{abstract}
${ }^{1}$ Embrapa Amazônia Oriental, Laboratório de Fitopatologia, Tv. Dr. Eneas Pinheiro, s/n, Marco, CEP 66095-100, Belém-PA, Brasil. Caixa Postal 48. E-mail: ruth.benchimol@embrapa.br; moacyr.dias-filho@embrapa.br

${ }^{2}$ University of Guelph, Department of Environmental Biology, 50 Stone Road East, Guelph-ON, Canada, N1G 2W1. E-mail: jcsutton@uoguelph.ca

${ }^{3}$ Comissão Executiva do Plano da Lavoura Cacaueira, Rodovia Itabuna, s/n - km 10, Zona Rural, CEP 45604-811, Itabuna-BA, Brasil. E-mail: clebernbastos@hotmail.com

${ }^{4}$ Universidade Federal Rural da Amazônia, Instituto de Ciências Agrárias, Av. Presidente Tancredo Neves, 2501, Montese, CEP 66077-530, Belém-PA, Brasil. Caixa Postal 917. E-mail: carinamelosilva@gmail.com
\end{abstract}

\begin{abstract}
Fusariosis (Fusarium solani f.sp. piperis) is one of the most damaging diseases of black pepper crop in the Amazon zone and the application of organic materials to the soil may be an alternative to control this disease. Leaf residues of Piper aduncum were evaluated before and after the extraction of essential oil, as additives to the soil inoculated with Fusarium solani, in the survival and morphophysiological behavior of black pepper seedlings. The experiments were conducted at Embrapa Eastern Amazônia, Belém, PA. The effects of the by-products of the distillation of the essential oil of $P$. aduncum on the survival to fusariosis in black pepper seedlings and the effect of dry and crushed leaves of $P$. aduncum, preincubated in the soil, in the incidence of fusariosis and in the behavior of black pepper seedlings were evaluated. The addition of solid residues from $P$. aduncum oil extraction to the soil increased the survival of seedlings by $80 \%$ and in the presence of dry and crushed leaves of $P$. aduncum the survival was $83 \%$. The net photosynthesis of the seedlings increased in the presence of residues of $P$. aduncum. The residues from the extraction of the essential oil of $P$. aduncum and its dry and crushed leaves, without oil extraction, have potential for use in the control of fusariosis in black pepper plants.
\end{abstract}

Key words: Fusarium solani f. sp. piperis; Piper nigrum; residues from essential oil extraction

\section{Sub-produtos de Piper aduncum no controle da fusariose da pimenteira-do-reino}

\section{RESUMO}

A fusariose (Fusarium solani f. sp. piperis) é uma das doenças mais prejudiciais à cultura da pimenteira-do-reino na Amazônia e a aplicação de materiais orgânicos no solo pode ser uma alternativa de controle dessa doença. Avaliou-se os resíduos foliares de Piper aduncum, antes e após a extração do óleo essencial, como aditivos ao solo inoculado com Fusarium solani, na sobrevivência e no comportamento morfofisiológico de mudas de pimenteira-do-reino. Os experimentos foram conduzidos na Embrapa Amazônia Oriental, Belém, PA. Foram avaliados os subprodutos da destilação do óleo essencial de $P$. aduncum na sobrevivência de mudas de pimenteira-do-reino à fusariose e o efeito de folhas secas e trituradas de $P$. aduncum, pré-incubadas no solo, na incidência de fusariose e no comportamento de mudas de pimenteira-do-reino. A adição de resíduos sólidos da extração de óleo de $P$. aduncum ao solo aumentou a sobrevivência de mudas à fusariose em $80 \%$ e na presença de folhas secas e trituradas de $P$. aduncum o incremento médio na sobrevivência foi de $83 \%$. A fotossíntese líquida das mudas aumentou na presença dos resíduos de $P$. aduncum. Os resíduos da extração do óleo essencial de $P$. aduncum e de suas folhas secas e trituradas, sem extração do óleo, tem potencial de uso no controle da fusariose da pimenteira-do-reino.

Palavras-chave: Fusarium solani f. sp. piperis; Piper nigrum; resíduos da extração de óleo essencial 


\section{Introduction}

Root rot and branch drying in black pepper plants, both denominated fusariosis, are caused by the fungus Fusarium solani (Mart.) Sacc. f. sp. piperis Albuq. (FSP), and its teleomorph, Nectria haematococca f.sp. piperis F.C. Albuq. \& Ferraz, an ascomycete of the Nectriaceae family (Albuquerque, 1964). The fungus $F$. solani $f$. sp. piperis affects the root system of the plant, causing root rot and leaf fall, and ultimate death (Silva \& Souza, 2009).

Root rot disease in Brazil has been responsible for the elimination of entire plantations of Piper nigrum L., with economic losses of millions of dollars per year and there is no efficient control measure against the pathogen and no disease-resistant cultivars (D'Addazio et al., 2016). The genetic variation between pepper genotypes in Brazil and the degree of susceptibility of currently available cultivars to the disease remain unknown, which makes it difficult to perform genetic control of fusariosis (Castro et al., 2016). As for chemical control, although the application of cupric fungicides can keep fusariosis of black pepper under control in propagators (Tremacoldi, 2010), there are restrictions on the use of fungicides due to environmental contamination and residues that may persist in the unprocessed products (Marín et al., 2008).

As an alternative to phytopathogen control, essential oils, secondary metabolic products of plants, can be used in various parts of the plant, such as leaves and stems (Scherer et al., 2009). These oils may contain secondary compounds with biological activity with potential action against plant pathogens (Schwan-Estrada, 2009).

Venturoso et al. (2011), observed fungistatic activity of clove extract on the development of Fusarium solani, Aspergillus sp., Penicillium sp., Colletotrichum sp., Cercospora kikuchii and Phomopsis sp., highlighting the use of natural products in the control of phytopathogens as a measure of preserving the environment. Seixas et al. (2011) observed a fungitoxic effect of 15,20 and $25 \mu \mathrm{L}$ of the citronella grass essential oil with $100 \%$ mycelial inhibition of Fusarium subglutinans, an etiological agent of fusariosis in pineapple crop (Ananas comosus), also stating that the phytosanitary control based on essential oils can be an effective and low-environmental impact-method in combating disease-causing pathogens in different plant species.

The objective of this work was to test the effect of foliar residues of $P$. aduncum, before and after the extraction of its essential oil, as additives to soil inoculated with $F$. solani f. sp. piperis, on the survival and morphophysiological behavior of young black pepper plants.

\section{Material and Methods}

\section{Effect of by-products of the distillation of Piper aduncum essential oil on the survival of red pepper seedlings to fusariosis.}

The experiments were conducted in the Experimental Field of Embrapa Eastern Amazônia (01 ${ }^{\circ} 8^{\prime} \mathrm{S}$; 4827' W), in Belém, $\mathrm{PA}$, in a semi-controlled environment, with $50 \%$ interception of sunlight, with temperature varying $25-35^{\circ} \mathrm{C}$ and relative air humidity ranging between $80-95 \%$.

The liquid residues (slurry) and the solid residues from the extraction of the essential oil of $P$. aduncum used in the experiments were provided by the Executive Committee of the Cocoa Plan (CEPLAC/SUPOR). The slurry was kept under refrigeration $\left(8 \pm 2^{\circ} \mathrm{C}\right)$ until use. The solid was dried in a forced air circulation oven $\left(75^{\circ} \mathrm{C}\right)$ for three days and ground to the powder form immediately prior to use in the experiment.

The strains of $F$. solani f. sp. piperis (FSP) used in all experiments were obtained from the collection of phytopathogenic fungi from the Phytopathology Laboratory of Embrapa Eastern Amazônia, in Belém, PA. To obtain the soilinoculum, the fungus was multiplied in vials with a capacity of $500 \mathrm{ml}$ containing $200 \mathrm{~g}$ of soil medium + wheat bran (4:1 mass/ mass). Pathogen culture disks in Potato-Dextrose-Agar (PDA), with $7 \mathrm{~mm}$ diameter, were transferred to individual flasks and incubated for 15 days $\left(27 \pm 1^{\circ} \mathrm{C} ; 12 \mathrm{~h}\right.$ photoperiod). Prior to use, the inoculum was homogenized and the concentration determined by the serial dilution method.

Non-sterilized soil from forest area were put in plastic pots $2 \mathrm{~kg}$ capacity, with $3 \%$ of solid residues (mass $/$ mass) or $0.35 \%$ of solid residues (mass/volume), with or without $0.5 \%$ of soil inoculum (484 spores g-1 soil), where two-node cuttings (one per pot) of black pepper were planted; this cuttings were obtained from ornamental branches from mother plants of Guajarina cultivar, pre-rooted for 45,60 days in shaded beds containing charred rice straw. The survival of the plants was evaluated every 30 days during 150 days, observing the appearance of symptoms in the collection region, establishing two values $(0$ and 100) for the presence or absence of fusariosis. The dry matter production of the seedlings was evaluated at the end of the experiment at 240 days, by determining the dry mass of leaves, stems and roots of each plant kept in a forced circulation oven $\left(\right.$ at $75^{\circ} \mathrm{C}$ ) for 72 hours. The leaf, stem and root mass ratios per unit mass of the whole seedling were used for the calculation of biomass allocation. The photosynthetic behavior of the plants was measured at the end of the experiment ( 240 days), using the newest, intact and fully developed leaf of each plant. Measurements were taken from 9am to 11am using a portable photosynthesis system (Model LI-6200, LI-COR Inc., Lincoln, NE, USA).

Effect of dry and crushed leaves of $P$. aduncum, preincubated on soil, on the incidence of fusariosis and on the behavior of black pepper seedlings

Green leaves of $P$. aduncum collected in the experimental field of Embrapa Western Amazônia were dried in a forced circulation oven $\left(75^{\circ} \mathrm{C}\right)$ for 72 hours and crushed to produce powder (foliar residues). FSP inoculum was obtained by transferring $7 \mathrm{~mm}$ diameter discs obtained from PDA cultures with seven days of growth to Petri dishes containing the same culture medium maintained under alternating light regime (12 $\mathrm{h}$ light/12 h dark) for another seven days. Autoclaved forest soil (for two consecutive days) $\left(120^{\circ} \mathrm{C}\right.$ for $\left.1 \mathrm{~h}\right)$ and natural soil (unsterilized forest soil) were used.

The foliar residues of $P$. aduncum were incorporated into the soil contained in the pots $(1 \mathrm{~kg})$ at concentrations of $1.5 \%$ 
and 3.0\% (mass $/$ mass), which were kept in a greenhouse for 15 days. After this period, $20 \mathrm{ml}$ of the aqueous inoculum suspension containing $5 \times 105$ spores $\mathrm{ml}^{-1}$ were added to each pot, and the pots were maintained under the same conditions as before for another 30 days when the rooted cuttings were transplanted. The control treatment was inoculated only with sterile distilled water, without inoculum of the pathogen. Twelve treatments were tested in a completely randomized experimental design, in a $2 \times 2 \times 3$ factorial arrangement. The evaluation was made based on plant mortality parameters at 30, 60 and 90 days, establishing two values (0 and 100), for the presence and absence of fusariosis symptoms in the plant collection, respectively.

Data corresponding to plant survival were analyzed using repeated measures ANOVA. Data on dry mass production and biomass allocation were $\log$ and arcsine $V_{\mathrm{X}} / 100$ transformed, respectively, for the univariate test procedure of significance, using the Generalized Linear Models (GLM). Net photosynthetic rate data were analyzed by the univariate significance test, using GLM. The homogeneity of variances for each ANOVA was tested using the Levene test and the Tukey test was applied, when appropriate. The statistical program STATISTICA for Windows 5.5 was used to analyze the data.

\section{Results}

Effect of by-products of distillation of Piper aduncum essential oil on the survival to fusariosis of black pepper seedlings.

In the control treatment, the survival of black pepper seedlings reached $100 \%$, regardless of the type of residue added to the soil. In soil inoculated with spores of the pathogen and given solid residues (SR) from the extraction of the essential oil of $P$. aduncum, the survival of the seedlings reached $45 \%$, being significantly higher than the seedlings grown in soil without these residues, or treated soil with liquid residues (LR). The survival of the seedlings in soil with liquid residues, solid residues and without residues can be observed in Figure 1.

Seedlings cultivated in soil with $P$. aduncum residues produced significantly higher dry mass, corresponding to increases of 78 and $324 \%$ in soil with liquid and solid residues, respectively (Figures 2 and 3 ).

The beneficial effect of the solid foliar residues obtained after extraction of the essential oil of $P$. aduncum in the increase of the black pepper seedlings survival can be attributed to the possible antifungal action of some components present in the leaves of this Piperaceae, of the essential oil itself, which may remain in the residues, even after extraction (Navickiene et al., 2006).

P. aduncum oil according to Silva et al. (2013) is composed of dilapiol, myrcene, cis-ocimene, beta-caryophyllene and myristicin, components that may interfere with plant growth and pest and disease control. The storage and processing stages may influence the concentration of the oil, mainly environmental factors such as temperature and humidity may cause quality losses in the material, reducing or eliminating its

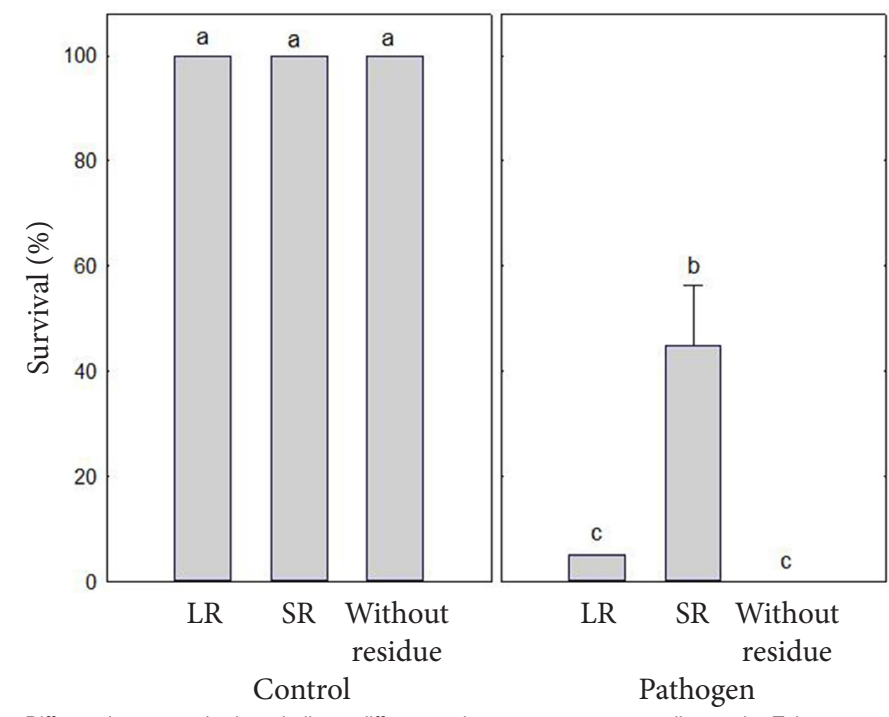

Different letters on the bars indicate differences between means, according to the Tukey test at $5 \%$ probability.

Figure 1. Survival after 150 days of black pepper seedlings in non-inoculated soil (control) (A) or soil inoculated with Fusarium solani (pathogen) spores (B), with liquid (LR) or solid (SR) residues of $P$. aduncum essential oil extraction. The data are means + standard error.

\section{A.}

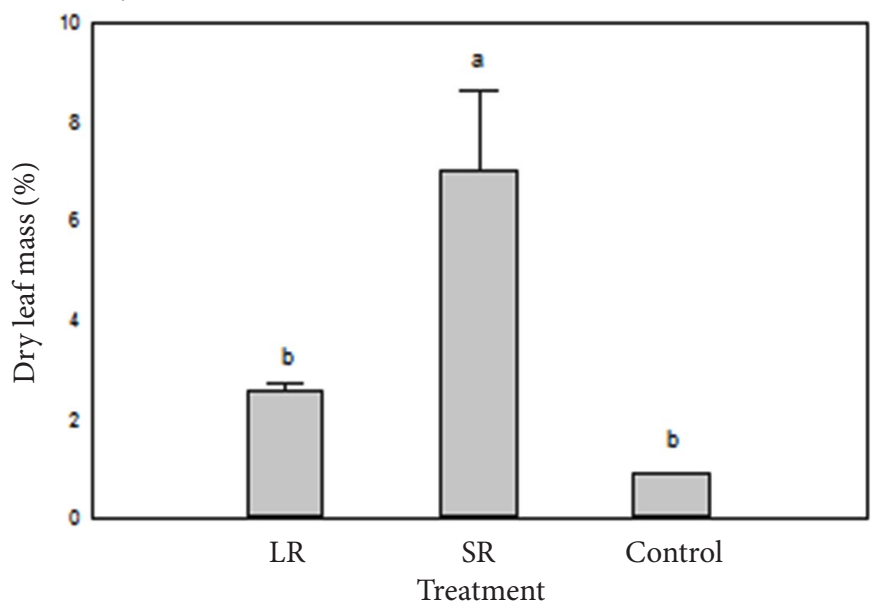

B.

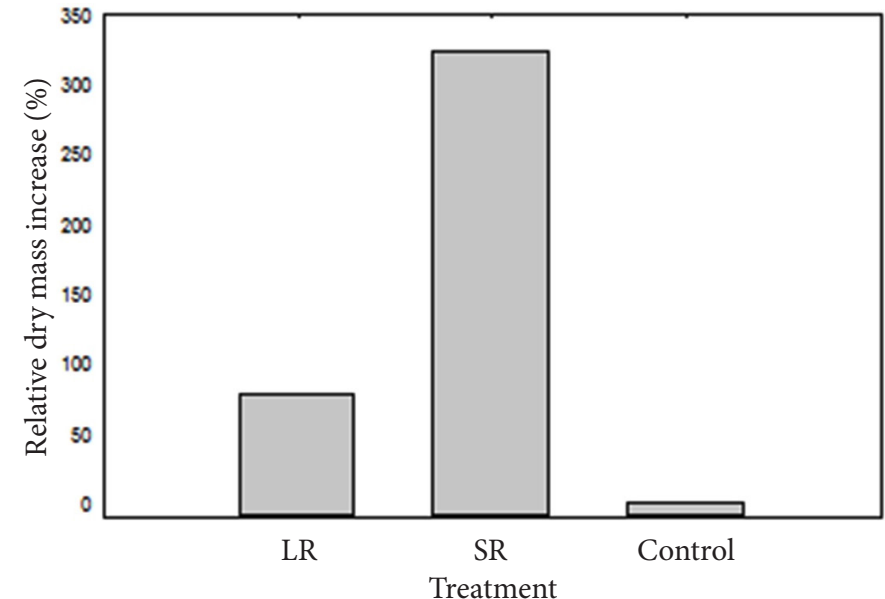

Different letters on the bars indicate differences between means, according to the Tukey test at $5 \%$ probability.

Figure 2. Dry matter production of leaves (A) and percentage increase in the production of relative dry mass (B) of black pepper seedlings after 150 days of cultivation in soil with liquid (LR) or solid (SR) residues of $P$. aduncum essential oil extraction. 


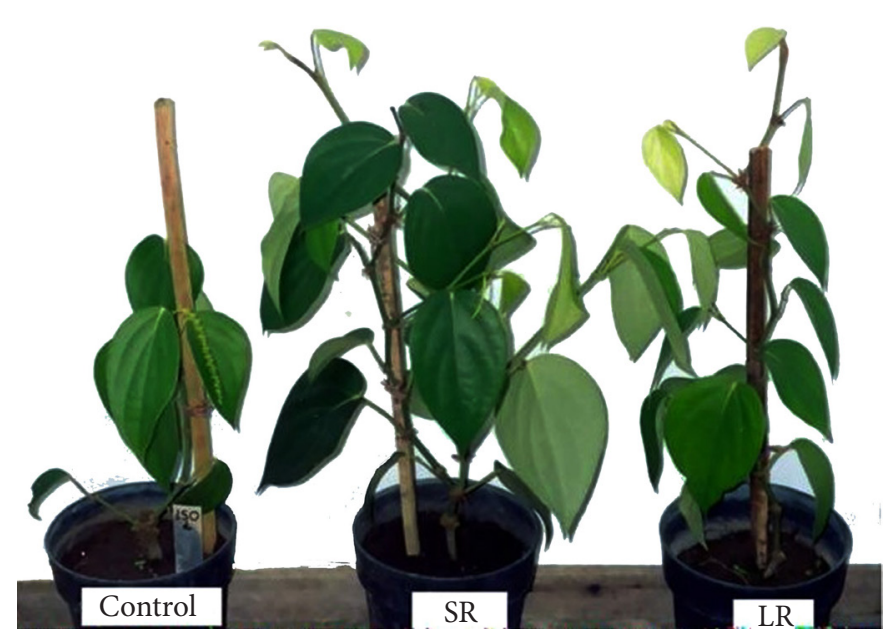

Figure 3. Black pepper seedlings after 150 days of cultivation on solid (SR) and liquid (LR) residues of $P$. aduncum essential oil extraction.

use as a source of natural dilapiol (Silva et al., 2015). Thus, because solid residues are subjected to less processing than liquid residues may contain higher concentration of chemical compounds explaining the greater survival of plants.

A tendency of plants cultivated in the presence of solid and liquid residues to allocate carbon (biomass) preferentially to the aerial part of the plant, mainly the leaves to the detriment of the root system was observed (Figure 4A), indicating the beneficial effect of these substances in the acquisition of nutrients, probably Nitrogen, by plants. A characteristic of plants with high $\mathrm{N}$ supply is the increase of the biomass allocation to the aerial part, mainly to the leaves (Sims et al., 2012).

The net photosynthesis of the seedlings in soil with residues of $P$. aduncum was higher than that of those cultivated in soil without residues (control), suggesting a beneficial effect on the general physiological behavior of the plants. However, no difference was observed in the net photosynthesis between the two types of residues (Figure 4B).

The action of the nutrients incorporated in the soil by the addition of the residues, at least in part, was responsible for the increase in the photosynthetic rate and the dry mass production of the black pepper seedlings. $P$. aduncum leaf residue, analyzed before and after the extraction of essential oil, indicate high levels of nitrogen, potassium, calcium and also some micronutrients such as Boron, Copper, Iron, Manganese and Zinc (Bastos, 2009).

Hartemink \& O'Sullivan (2001) studied the decomposition of leaves of species of secondary vegetation in Papua New Guinea, and showed that the leaves of $P$. aduncum decompose rapidly, being a significant source of potassium, which is one of the most important nutrients required by black pepper (Flores et al., 2012). The biomass allocation pattern observed in black pepper seedlings cultivated in soil with $P$. aduncun residues suggests that this soil had high nitrogen availability (Sims et al., 2012).

Effect of dry and crushed leaves of $P$. aduncum preincubated in the soil on the incidence of fusariosis and behavior of pepper seedlings.

The interaction between dry and crushed leaves of $P$. aduncum (FPAD), presence of $F$. solani f. sp. piperis (FSP)
A.

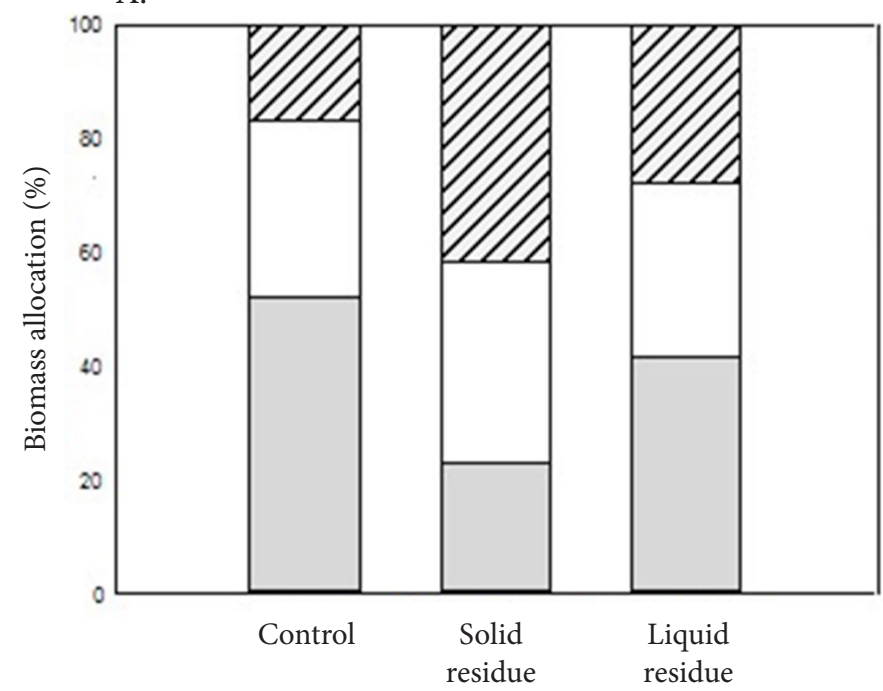

B.

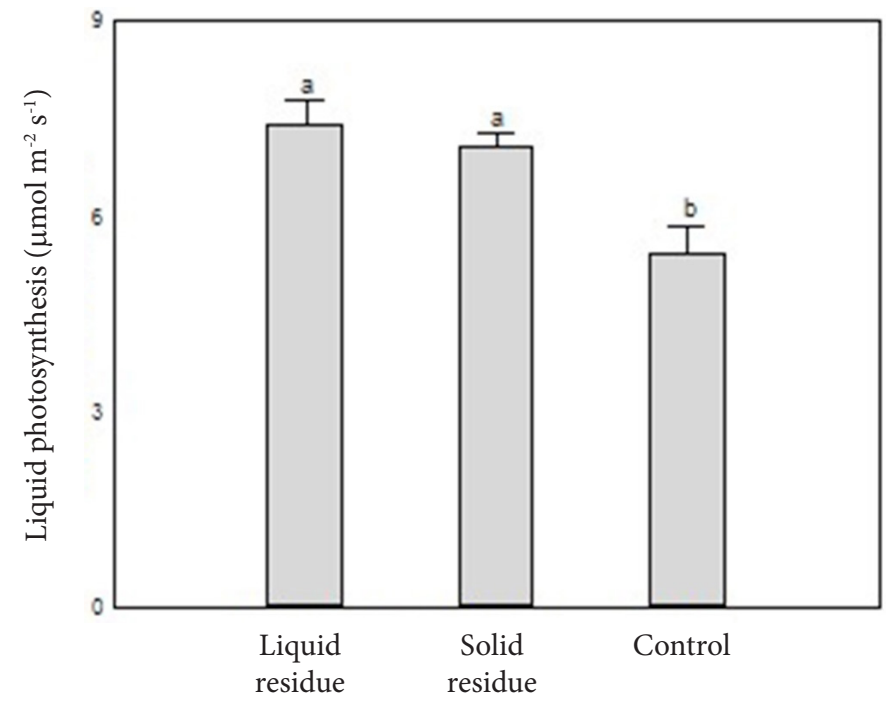

Different letters on the bars indicate differences between means, according to the Tukey test at $5 \%$ probability.

Figure 4. A. Mean Fraction of biomass (\%) allocated to roots (dark area), stems (light area) and leaves (striped area); B - Net photosynthesis of black pepper plants, after 150 days of cultivation in soil with extracts of $P$. aduncum essential oil.

and evaluation period had a significant effect on the survival of black pepper seedlings to fusariosis. The presence of FPAD in the soil reduced the mortality of the seedlings by $66.7 \%$ in the concentration of $1.5 \%$ and by $83.3 \%$ in the concentration of $3 \%$ of this material, regardless of whether the soil was autoclaved or not (Figure 5).

The total dry mass production of seedlings in soil with FPAD in soil not inoculated with FSP was higher than that in soil without this material, regardless of whether the soil was autoclaved or not. The dry mass production in seedlings grown in $3.0 \%$ FPAD soil was the same both in plants grown in soil inoculated and not inoculated with the pathogen. However, in soil enriched with $1.5 \%$ of FPAD, the total dry mass production was lower in the presence of the pathogen (Figure 6).

The addition of $3.0 \%$ of FPAD to natural/non-infested, natural/infested, autoclaved/non-infested and autoclaved/ infested soils increased the dry mass production of the plants 


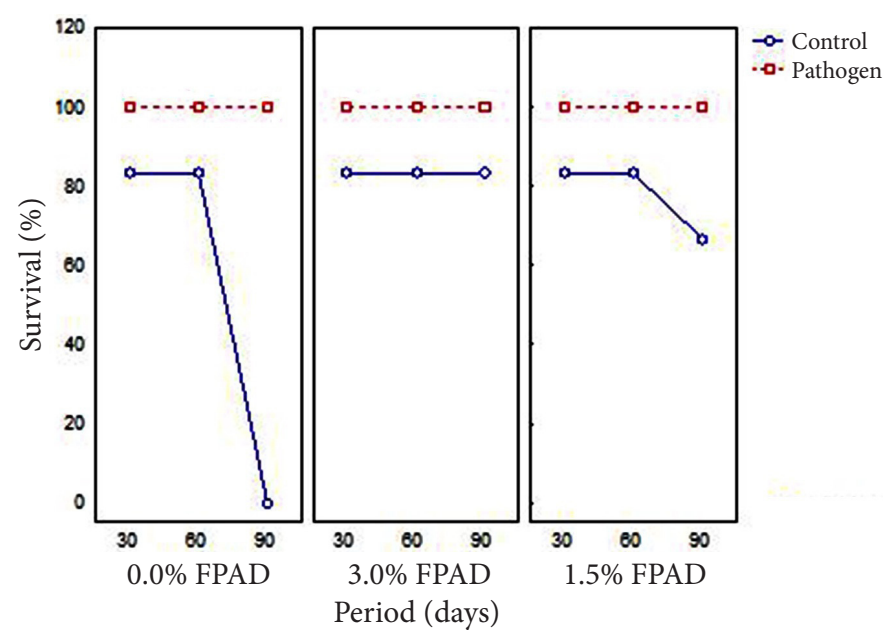

Figure 5. Survival of black pepper plants in soil infested with $F$. solani f. sp. piperis and with dry and crushed leaves of $P$. aduncum (FPAD).

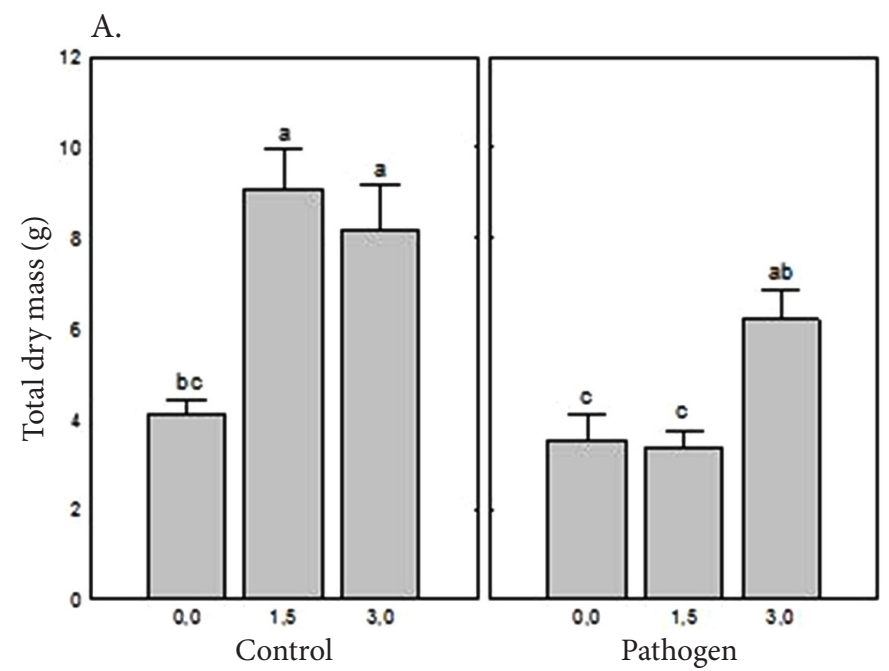

B.

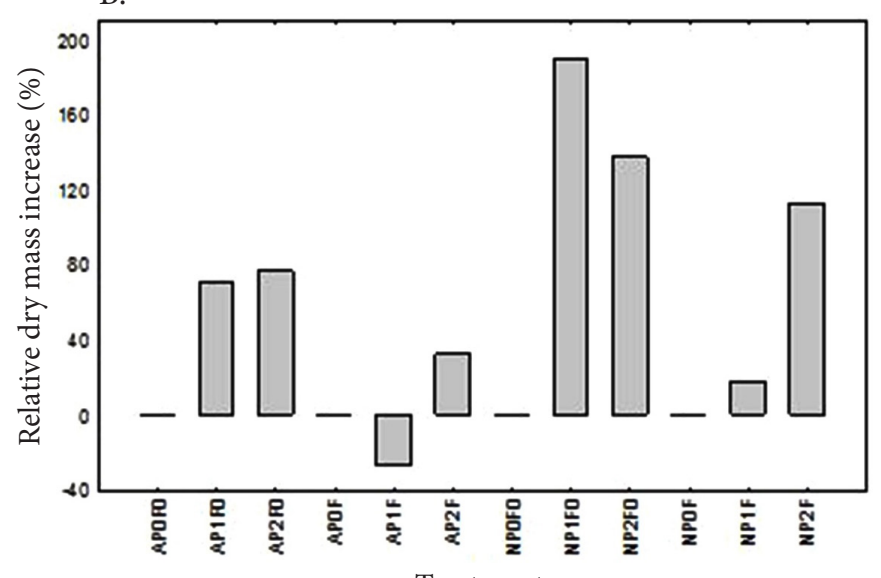

Treatment

$\mathrm{A}=$ autoclaved soil; $\mathrm{N}=$ natural soil; $\mathrm{P0}=$ without $\mathrm{FPAD} ; \mathrm{P} 1=1.5 \% \mathrm{FPAD} ; \mathrm{P} 2=3.0 \% \mathrm{FPAD} ; \mathrm{F}=$ with pathogen; $F 0=$ without pathogen. Data are means + standard error. Different letters on the bars indicate differences between means, according to the Tukey test at $5 \%$ probability.

Figure 6. A- Total dry mass of black pepper plants after 90 days of cultivation in soil not inoculated (Control) or inoculated (Pathogen) with FSP spores and with dry leaves of $P$. aduncum, in three concentrations $(0,1.5$ and $3 \%$ ). B- Relative dry mass increase in black pepper seedlings cultivated in autoclaved or natural soil, with two concentrations of dry and crushed leaves of $P$. aduncum (FPAD). by $137,113,77$ and $32 \%$, respectively. The respective values of relative increase or decrease in dry mass production for the addition of $1.5 \%$ FPAD to soil were $190,18,71$ and $-27 \%$ (Figure 6B). The negative increase observed in the dry mass of the plants in soil with $1.5 \%$ of FPAD was probably due to the insufficient amount of nutrients released in the soil by this concentration of the material, together with the presence of the pathogen.

Regardless of whether the soil was autoclaved or not, the seedlings tended to allocate carbon to the aerial part, even in the presence of FSP, especially on natural soil. In the plants cultivated in the presence of FPAD, the biomass allocation was higher for the leaves. The soil type $\mathrm{x}$ FPAD concentration $\mathrm{x}$ pathogen interaction was significant for the allocation of root biomass.

The incorporation of residues from P. aduncum essential oil extraction into the soil was effective in reducing the incidence of the witches' broom disease" of the cocoa tree in greenhouse (Bastos, 2009) and reduced the reproduction of Meloidogyne incognita in tomato culture (Silva et al., 2007). Also, due to the broad spectrum of antimycotic action of the essential oil of $P$. aduncum "in vitro" (Navickiene et al., 2006) and the fungicidal activity of the essential oil of $P$. marginatum Jacq. against Fosarium oxysporum (Schlecht)) "in vitro" (Santos et al., 2011), it is possible that foliar residues of this piperaceae have potential for use in the control of fusariosis in black pepper.

The control of fusariosis with the use of $P$. aduncum extracts agrees with other works that have reported the efficiency of essential oils. Silva \& Bastos (2007) observed fungitoxic action of the essential oils of $P$. callosum, $P$. marginatum var. anisatum and $P$. enckea and stated that studies for the application of oils in the control of phytopathogens results in the possibility of using natural products with low toxicity, thus less aggressive to the environment.

\section{Conclusions}

Solid residues from the extraction of the essential oil of Piper aduncum incorporated into the soil increased the dry mass production of black pepper seedlings.

Dried and crushed leaves of $P$. aduncum incorporated into the soil reduced the mortality of black pepper seedlings by fusariosis in up to $83.3 \%$.

Solid residues from the extraction of the essential oil and crushed and dry leaves of $P$. aduncum have potential for use in the control of fusariosis in black pepper seedlings.

\section{Literature Cited}

Albuquerque, F.C. Podridão das raízes e do pé da pimentado-reino - segunda contribuição da seção de fitopatologia do IPEAN. Belém; IPEAN, 1964. 16 p. (IPEAN. Circular Técnica, 8). https://ainfo.cnptia.embrapa.br/digital/ bitstream/item/57314/1/IPEAN-Cir8.pdf. 10 Fev. 2017.

Bastos, C.N. Efeito da incorporação de resíduos foliares de Piper aduncum ao solo no controle da vassoura-de-bruxa do cacaueiro em casa-de-vegetação. Agrotrópica, v.21, n.2, p.127-132, 2009. http://www.ceplac.gov.br/paginas/ agrotropica/revistas/agrotropica_21.zip. 04 Jan. 2017. 
Castro, G.L.S.; Lemos, O.F.; Tremacoldi, C.R.; Moraes, F.K.C.; Santos, L.R.R.; Pinheiro, H.A. Susceptibility of in vitro black pepper plant to the filtrate from a Fusarium solani $\mathrm{f}$. sp. piperis culture. Plant Cell, Tissue and Organ Culture, v.127, n.1, p.263-268, 2016. https://doi.org/10.1007/s11240016-1031-4.

D’Addazio, V.; Santos, R.A.A.; Leitão, A.S.B.; Silva, M.B.; Fernandes, A.A.; Falqueto, A.R. Evaluation of in vitro inhibition of mycelial growth of Fusarium solani f. sp. piperis by different products in Brazil. African Journal of Microbiology Research, v.10, n.47, p.1992-1998, 2016. https://doi.org/10.5897/AJMR2016.8292.

Flores, R.A.; Almeida, T.B.F.; Politi1, L.S.; Prado, R.M.; Barbosa, J.C. Crescimento e desordem nutricional em pimenteira malagueta cultivada em soluções nutritivas suprimidas de macronutrients. Revista Brasileira de Ciências Agrárias, v.7, n.1, p.104-110, 2012. https://doi.org/10.5039/ agraria.v7i1a1648.

Hartemink, A.E.; O’Sullivan, J.N. Leaf litter decomposition of Piper aduncum, Gliricidia sepium and Imperata cylindrica in the humid lowlands of Papua New Guinea. Plant and Soil, v.230, n.1, p.115-124, 2001. https://doi. org/10.1023/A:1004868502539.

Marin, A.; Gil, I.M.; Flores, P.; Selma, M.V. Microbial Quality and Bioactive Constituents of Sweet Peppers from Sustainable Production Systems. Journal of Agricultural and Food Chemistry, v.56, n.23, p.11334-11341, 2008. https:// doi.org/10.1021/jf8025106.

Navickiene, H.M.D.; Morandim, A.; Alécio, A.C.; Regasini, L.S.O.; Bergamo, D.C.B.; Telascrea, M.; Cavalheiro, A.J.; Lopes, M.R.N.; Bolzani, V.D.S.; Furlan, M.; Marques M.R.O.M.; Young, M.C.M.; Kato, M.J. Composition and antifungal activity of essential oils from Piper aduncum, Piper arboreum and Piper tuberculatum. Química Nova, v.29, n.3, p.467-470, 2006. https://doi.org/10.1590/S010040422006000300012.

Santos, M.R.A.; Lima, R.A.; Fernandes, C.F.; Silva, A.G.; Facundo, V.A. Antifungal activity of Piper marginatum L. (Piperaceae) essential oil on "in vitro" Fusarium oxysporum (SCHLECHT). Revista Saúde e Pesquisa, v.4, n.1, p.09-14, 2011. https://doi.org/10.1590/S1517-83822011000300020.

Scherer, R.; Wagner, R.; Duarte, M.C.T.; Godoy, H.T. Composição e atividade antioxidante e antimicrobiana dos óleos essenciais de cravo-da- índia, citronela e palmarosa. Revista Brasileira de Plantas Medicinais, v.11, n.4, p.442-449, 2009. https://doi.org/10.1590/S1516-05722009000400013.

Schwan-Estrada, K.R.F. Extratos vegetais e de cogumelos no controle de doenças de plantas. Horticultura Brasileira, v.27, n.2, suplemento, p.S4038-S4045, 2009. http://www. abhorticultura.com.br/eventosx/trabalhos/ev_3/mr_4 artigo_katia_regina_estrada.pdf. 10 Jan. 2017.
Seixas, P.T.L.; Castro, H.C.; Santos, G.R.; Cardoso, D.P. Controle fitopatológico do Fusarium subglutinans pelo óleo essencial do capimcitronela (Cymbopogon nardus L.) e do composto citronelal. Revista Brasileira de Plantas Medicinais, v.13, n. spe, p.523-526, 2011. https://doi. org/10.1590/S1516-05722011000500003.

Silva, A.L.; Chaves, F.C.M.; Lameira, R.C.; Bizzo, H.R. Rendimento e composição do óleo essencial de Piper aduncum L. cultivado em Manaus, AM, em função da densidade de plantas e épocas de corte. Revista Brasileira de Plantas Medicinais, v.15, n.4, p.670-674, 2013. https:// doi.org/10.1590/S1516-05722013000500007.

Silva, C.L.O.C.; Faria, L.J.G.; Costa, C.M.L. Comportamento higroscópico de partes aéreas de pimenta-de-macaco (Piper aduncum L.). Revista Brasileira de Engenharia Agrícola e Ambiental, v.19, n.4, p.376-381, 2015. https:// doi.org/10.1590/1807-1929/agriambi.v19n4p376-381.

Silva, D.M.M.H.; Bastos, C.N. Atividade Antifúngica de Óleos Essenciais de Espécies de Piper sobre Crinipellis perniciosa, Phytophthora palmivora e Phytophthora capsici. Fitopatologia brasileira, v.32, n.2, 2007. https:// doi.org/10.1590/S0100-41582007000200008.

Silva, G.S.; Pereira, A.L.; Bastos, C.N.; Mendonça, V.C.M. Efeito da incorporação de resíduos foliares de Piper aduncum ao solo sobre o parasitismo de Meloidogyne incognita em Tomateiro. Nematologia Brasileira, v.30, n.2, p.219-222, 2007. http://docentes.esalq.usp.br/sbn/ nbonline/ol\%20302/219-222\%20pb.pdf. 03 Mar. 2017.

Silva, R.S.; Souza, C.R.B. Extração e análise eletroforética em gel de poliacrilamida (SDS-PAGE) de proteínas totais de folhas e raízes de Piper tuberculatum. Acta Amazônica, v.39, n.2, p.255-260, 2009. https://doi.org/10.1590/S004459672009000200002.

Sims, L.; Pastor, J.; Lee, T.; Dewey, B. Nitrogen, phosphorus and light effects on growth and allocation of biomass and nutrients in wild rice. Oecologia, v.170, n.1, p.65-76, 2012. https://doi.org/10.1007/s00442-012-2296-X.

Tremacoldi, C.R. Principais doenças fúngicas da pimenteirado-reino no estado do Pará e recomendações de controle. Belém: Embrapa Amazônia Oriental, 2010. 23p. ((Embrapa Amazônia Oriental. Documentos, 367). https:// www.infoteca.cnptia.embrapa.br/bitstream/doc/883996/1/ Doc367.pdf. 27 Mar. 2017.

Venturoso, L.R.; Bacchi, L.M.; Gavassoni, W.L.; Conus, L.A.; Pontim, B.C.A.; Bergamin, A.C. Atividade antifúngica de extratos vegetais sobre o desenvolvimento de fitopatógenos. Summa Phytopathology, v.37, n.1, p.18-23, 2011. https:// doi.org/10.1590/S0100-54052011000100003. 